Research article

\title{
HEMATOLOGICAL AND SERUM BIOCHEMICAL REFERENCE VALUES FOR THE POSAVINA AND CROATIAN COLDBLOOD HORSE BREEDS
}

\author{
PAĐEN Lana슬 GOMERČIĆ Tomislav², ĐURAS Martina ${ }^{3}$, ARBANASIĆ Haidi, \\ GALOV Ana ${ }^{4 *}$
}

${ }^{1}$ Department of Physiology and Radiobiology, Faculty of Veterinary Medicine, University of Zagreb, Zagreb, Croatia; ${ }^{2}$ Department of Biology, Faculty of Veterinary Medicine, University of Zagreb, Zagreb, Croatia; ${ }^{3}$ Department of Anatomy, Histology and Embryology, Faculty of Veterinary Medicine, University of Zagreb, Zagreb, Croatia; ${ }^{4}$ Department of Animal Physiology, Faculty of Science, Division of Biology, University of Zagreb, Zagreb, Croatia

(Received 31 January; Accepted 04 April 2014)

In this study the hematological and biochemical parameters in the blood of indigenous Croatian working horse breeds were investigated. The Posavina and Croatian Coldblood horses are adapted to harsh environmental conditions and their blood parameters might differ from other horse breeds. The study was carried out on 100 mares and 12 stallions of ages from 2 to 19 years. Fifteen hematological and 19 biochemical parameters were analysed. Values of 22 parameters showed considerable overlapping with values obtained for other horse breeds, and substantial resemblance is evident with values reported for Pakistani working horses. Several reference values showed statistically significant effect of sex (Hb, ALB, CREA, TBIL and Ca where significantly higher in stallions; EOS, CK, ALP, UREA and Mg were significantly higher in mares). None of the parameters studied showed any differences associated with age. The adaptation of Posavina and Croatian Coldblood horses to the harsh environment of flooded pastures and the way of breeding might be reflected in their specific reference values. The obtained results enabled the establishment of hematological and biochemical reference values in the blood of Posavina and Croatian Coldblood horses that will in turn support clinical diagnosis and further research into horse physiology.

Key words: biochemistry, coldblood horses, hematology, Posavina horse, Croatian Coldblood horse, reference values

\section{INTRODUCTION}

The Posavina and Croatian Coldblood are indigenous Croatian working horse breeds. Posavina horse originated from uncontrolled crossing of mares of Slavonian - Posavina horse and other mares of unknown origin with warm-blooded (Arab, Lipizzan,

* Corresponding author: e-mail: ana.galov@biol.pmf.hr 
Nonius, Thoroughbred), and later, cold-blooded (Brabant, Ardennes, Percheron and Norico) stallions [1]. The history of Posavina horse is tightly interweaved with the history of the Croatian Coldblood. Ljubesic et al. [2] wrote about the Posavina horse as a type of Croatian Coldblood. The notion that Posavina horse is a variety or type of Croatian Coldblood and not a distinct breed is further emphasized by Mason [3]. In recent history, in the 1990s, due to economical and political reasons Posavina horses influenced heavily breeding of Croatian Coldbloods, as exclusively owners of Posavina horses received annual premiums [1]. In 1991 the Croatian Livestock Centre started creating Studbooks for Posavina and Croatian Coldblood horses. The Studbook for the Posavina horse breed was closed in 2004 [4], while creation of the Studbook for Croatian Coldbloods still proceeded until its formal closure in 2008 [5]. Although considered as different breeds, Ivankovic et al. [6] found, based on mitochondrial D-loop sequence variation, that the Posavina and the Croatian Coldblood horses were the most closely related populations. Furthermore, using microsatellite markers, Galov et al. [7] did not observe genetic differentiation between these two breeds. According to the Annual Report of horse breeding in the Republic of Croatia [8], in the 2010 the number of Posavina horses was 4909, with the largest number of animals bred in the area of Sisak-Moslavina County (69.81\%). Apart from this County, a growing area of this breed is also Zagreb County. In the same year, the number of Croatian Colblood horses was 6304, with 902 animals in the area of Sisak-Moslavina County [8]. In Europe, the coldblood autochthonous horse breeds have become endangered, as they lost their traditional use value as working animals [6]. However, floodplain areas along the Sava River and its tributaries are a rare eco-system with preserved traditional way of horse breeding and herding in general [9]. Posavina and Croatian Coldblood horses are kept together in coexistence with cows and pigs. All animals are fed on feeds that they find themselves. The mares are released in early spring on an open area of flooded pastures and before winter returned to the barn, so most of the time they are not under the owners' supervision. Breeding and health status are poorly controlled by owners and are therefore more exposed to natural selection. Because of the way of breeding, keeping and feeding, these horses are highly adapted to specific environment and climatic conditions in the region, and have characteristics that might be reflected in their physical status and consequently their hematological and serum biochemical parameters.

Hematological parameters, such as RBC (red blood cells), MCV (mean corpuscular volume), $\mathrm{Hb}$ (hemoglobin concentration), PCV (packed cell volume) and total and differential WBC (white blood cell) count, as well as biochemical parameters such as different enzyme activities, mineral concentrations and other serum substrates help clinicians to evaluate the health status of the specimen and diagnose infectious and some parasitic diseases, as well as to observe a recovery period. They also provide important information about the response to therapy, strength and systemic effect of disease and the metabolic state of the individual animal or herd [10]. Some of the hematological and biochemical values are of great interest in horses subjected to 
standardized field exercise tests [11-13]. The hematological and serum biochemical reference values of various horse breeds may differ due to genetic factors and/or various environmental factors (e.g. nutritional quality, availability of water, parasites and climate). For instance, coldblood horse breeds have a lower number of erythrocytes, lower hemoglobin, hematocrit and blood volume than hotblood horses.

Hematological data are available for several horse breeds, such as American miniature horse [14], Andalusian horse [15], Arab horse [16], Thoroughbred horse [17], Lipizzan horse [18], Quarter horse [19], Yugoslav Trotter [20], as well as for horses in general [21]. For Croatian working horse breeds, some hematological parameters are available for Murinsulaner horses [22]. However, no data on hematological and biochemical parameters have been published for the Posavina and Croatian Coldblood horse breeds.

The aim of this study was to determine hematological and biochemical reference values for Posavina and Croatian Coldblood horse breeds combined, as blood samples were collected prior to formal closure of their respective studbooks and all the individuals were kept together under the same conditions. Moreover, no genetic differentiation between them was observed [7]. Our aim was also to compare those reference values with already known reference values for other breeds of coldblood horses, hotblood horses and horses in general. We further aimed to determine any differences associated with sex and age of the studied horses.

\section{MATERIALS AND METHODS}

This study was carried out on 112 horses (100 mares and 12 stallions) of two Croatian working horse breeds - Posavina and Croatian Coldblood. Age of studied animals ranged between 2 and 19 years, with an average age of 8 years. Effects of age were analysed by dividing the animals into three (3-4, 5-6 and 11-12 years; stallions) and four (2-5, 6-10, 11-13 and 14-19 years; mares) age groups. Blood samples were collected during June and July 1999 and 2001 on six different locations in central Croatia (Figure 1). Stallions were housed in individual stalls under conditions of natural photoperiod and natural indoor temperature and under constant supervision of the owners, while mares were kept in an open system biocenosis of woods and marshy meadows. The animals were clinically healthy. Blood samples were taken by jugular vein puncture (vena jugularis externa) directly into Vacutainer ${ }^{\circledR}$ tubes with gel for biochemical analysis and Vacutainer ${ }^{\circledR}$ tubes for whole blood (EDTA). In the whole blood samples the number of red blood cells (RBC), hemoglobin concentration $(\mathrm{Hb})$, hematocrit (PCV), average volume of red blood cells in the blood (MCV), and total number of leukocytes (WBC) were determined using an automatic cell counter (model ZF, Coulter Electronics. Ltd., UK). Differential blood count (neutrophils NEU, eosinophils - EOS, basophils - BAS, monocytes - MON, lymphocytes - LYM) was determined on a blood smear using a light microscope at x 400 magnification. Blood serum was separated by centrifugation at $1600 \mathrm{~g}$ for $20 \mathrm{~min}$. The serum 
samples were stored at $-20^{\circ} \mathrm{C}$ until further analysis. Biochemical analysis included the activity of enzymes gamma-glutamyl transferase (GGT), aspartate aminotransferase (AST), alanine aminotransferase (ALT), creatine kinase (CK), alkaline phosphatase (ALP), lactate dehydrogenase (LDH) and amylase (AMYL), concentration of glucose (GLUC), albumin (ALB), total protein (TP), cholesterol (CHOL), triglycerides (TRI), calcium (Ca), phosphorus $(\mathrm{P})$, magnesium $(\mathrm{Mg})$, iron $(\mathrm{Fe})$, urea (UREA), creatinine (CREA) and total bilirubin (TBIL). Samples for biochemical analysis were processed using standard procedures with the biochemical analyzer Olympus AU 560 (Olympus Hamburg, Germany), using tests for Olympus. Statistical analyses were made using the computer program Statistica, version 9th (StatSoft, Inc., Tulsa, USA). After testing the normality (Kolmogorov-Smirnov and Shapiro-Wilk test) $\mathrm{t}$ - test were made for dependent samples. The significance level of 0.05 was adjusted by means of Bonferroni correction procedure.

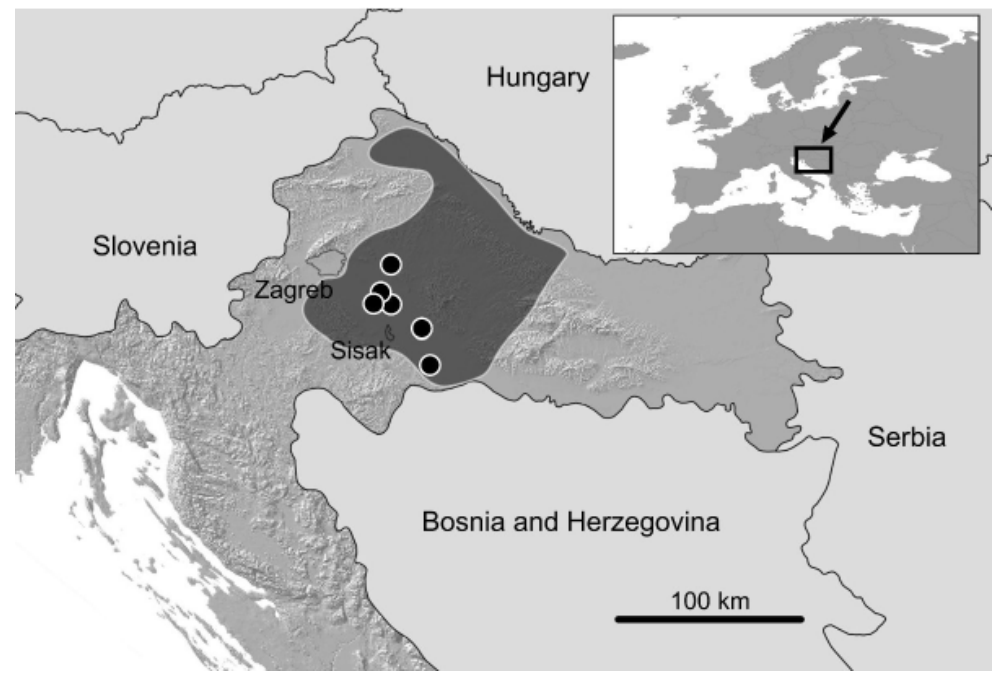

Figure 1. Geographical map of Croatia with black circles indicating areas where samples of Posavina and Croatian Coldblood horses were collected. The dark grey area indicates approximate distribution of the two Croatian working horse breeds

\section{RESULTS}

Mean value, standard deviation and range for the blood erythrocyte parameters $\mathrm{RBC}$, MCV, Hb, PCV), total and differential WBC count, enzymes activity (GGT, AST, ALT, $\mathrm{CK}$, ALP, LDH, AMYL), mineral concentrations (Ca, P, Mg, Fe) and other biochemical parameters (GLUC, ALB, TP, CHOL, TRI, UREA, CREA, TBIL) are presented in Tables 1 and 2. 


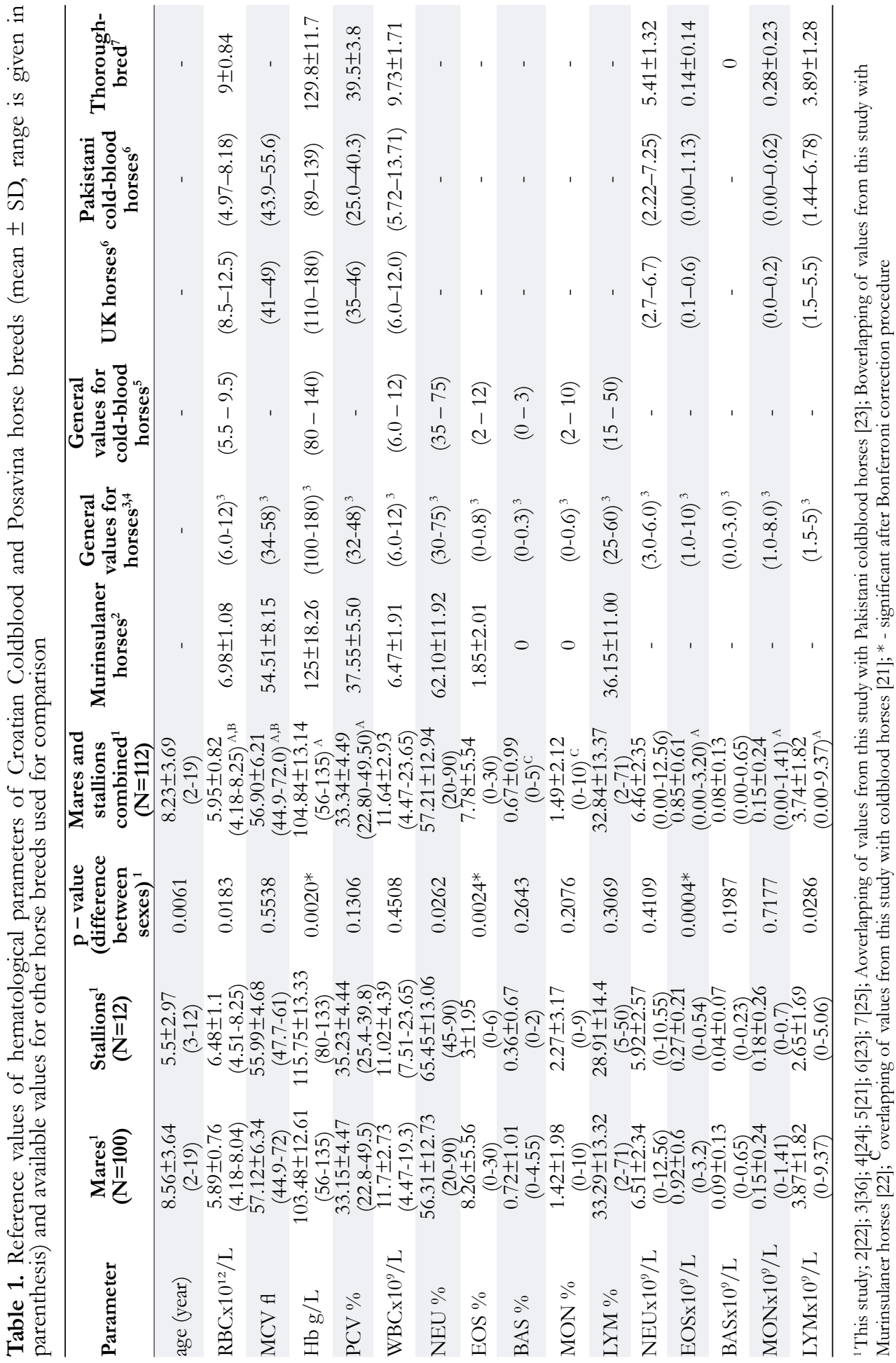




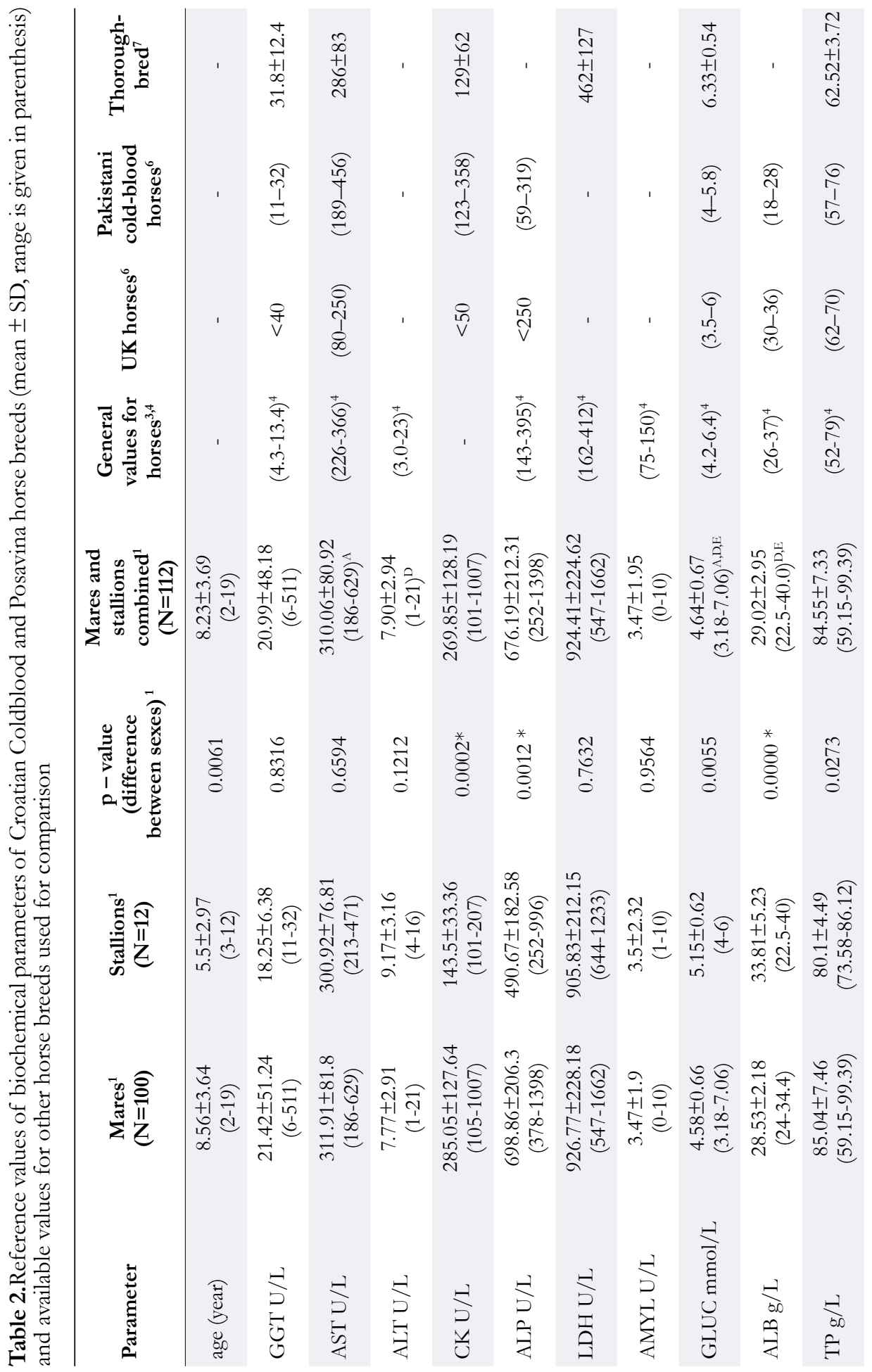




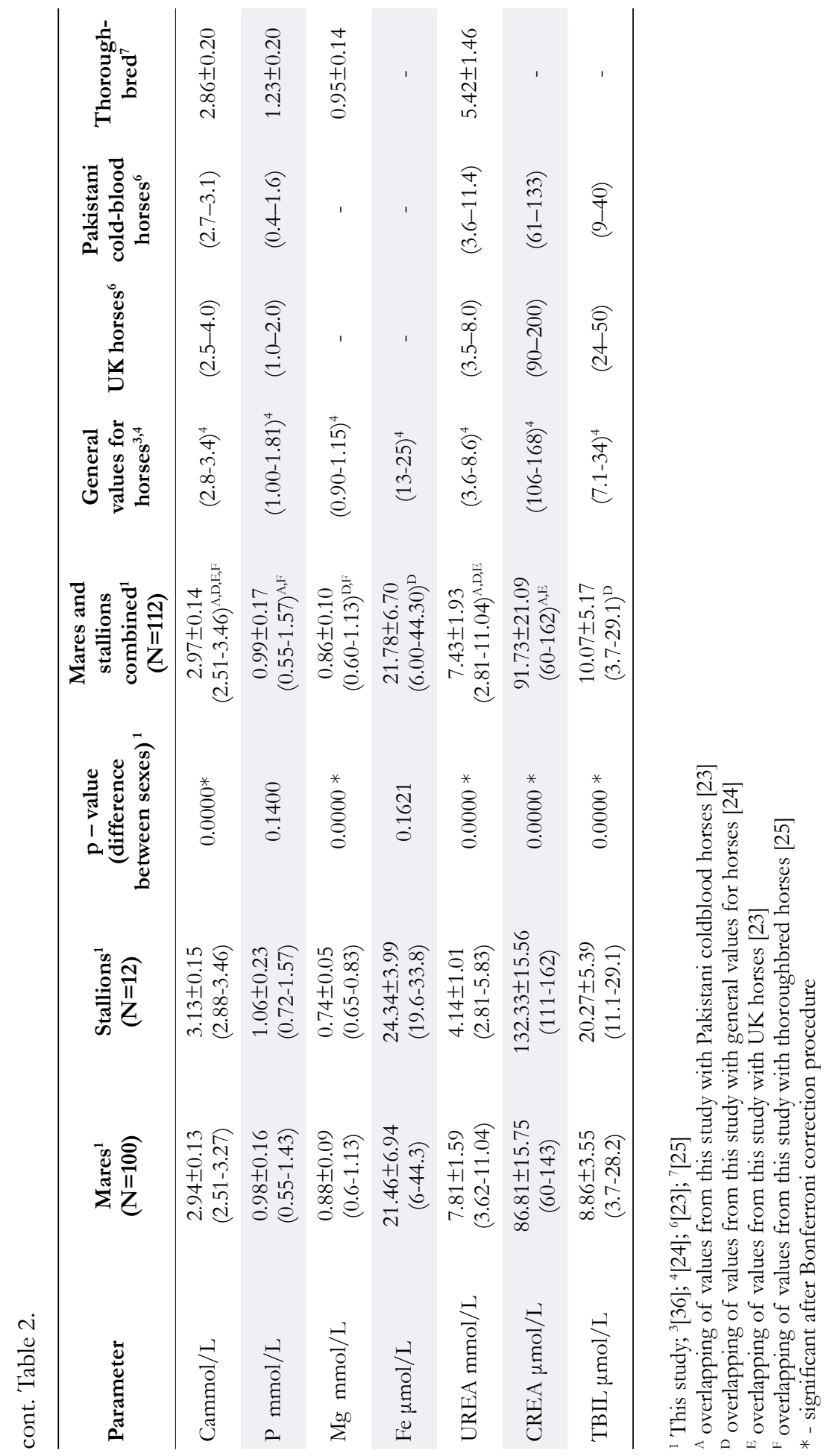


Hematology reference values for Posavina and Croatian Coldblood horses showed the greatest similarity with reference values for coldblood horses from Pakistan [23]. Of the 15 hematology reference intervals established for Posavina and Croatian Coldblood horses, 7 (marked with A in Table 1) overlapped considerably with published reference ranges for coldblood horses from Pakistan. Reference values for RBC and MCV of Posavina and Coldblood horses overlapped with mean values for Murinsulaner horses [22] (marked with B). Some of the investigated horse reference intervals somewhat overlapped, but were shifted noticeably higher (MCV, eosinophils $\%$, neutrophils $\%$, lymphocytes $\%$ ) or lower ( $\mathrm{Hb}$ ) than those available for other horse breeds (Table 1 ). The maximum values for WBC count and absolute neutrophil count in the Posavina and Croatian Colblood horse were considerably higher than those in Pakistan working horses (4.47-23.65 vs. 5.72-13.71 and 0-12.56 vs. 2.22-7.25, respectively). The mean value of WBC count in the Posavina and Coldblood horses was considerably higher than that in Murinsulaner horses (11.64 \pm 2.93 vs. $6.47 \pm 1.91)$. Relative eosinophil number in Posavina and Coldblood horses was considerably higher than that in Murinsulaner horses (7.78 \pm 5.54 vs. $1.85 \pm 2.01)$.

Biochemistry reference values for Posavina and Croatian Coldblood horse showed the greatest similarity with reference values for cold blooded horses from Pakistan [23]. Of the 19 biochemical reference intervals established for Posavina and Croatian Coldblood horses 6 (marked with A in Table 2) overlapped considerably with published reference ranges for coldblood horses from Pakistan [23]. Ten reference ranges of our horses (marked with D) overlapped with reference ranges for horses from biochemistry textbook [24], with considerably wider ranges of iron and urea for our horses. The maximum values for GGT, CK and ALP in the Posavina and Croatian Colblood horse were considerably higher than those in Pakistan working horses (6-511 vs. 11-32; 101 1007 vs. $123-358 ; 252-1398$ vs. 59-319, respectively). The entire reference value range for $\mathrm{LDH}$ in the tested horses were considerably higher than the maximum reference value for horses in general [24] (547-1662 vs. 162-412), while the entire reference value range for AMYL was considerably lower than minimum reference value for horses in general (0-10 vs. 75-150). Reference values for GLUC, ALB, Ca, UREA, CREA in our horses (marked with E) overlapped with reference values for UK horses [19]. Reference values for TP in Posavina and Croatian Coldblood horses were higher than that in Pakistan horses (59.15-99.39 vs. 57-76). Comparing reference values from the Croatian tested horses with reference values for Thoroughbreds [25] there is overlapping for $\mathrm{Ca}, \mathrm{P}$ and $\mathrm{Mg}$ reference values (marked with $\mathrm{F}$ in Table 2).

Several reference values showed a statistically significant effect of sex (Tables 1 and 2). $\mathrm{Hb}$, albumin, $\mathrm{Ca}$, creatinine and total bilirubin concentration values were significantly higher in stallions, whereas eosinophil count, CK, ALP, Mg and urea concentrations were significantly higher in mares. None of the parameters studied showed any differences associated with age in this study. 


\section{DISCUSSION}

In this study we established hematological and biochemical reference values for Posavina and Croatian Coldblood horses and evaluated them in the context of already known reference values for other breeds of coldblood horses, hotblood horses and horses in general.

The haematological and serum biochemical reference ranges in Tables 1 and 2 show that for most of the parameters (for 22 of a total of 34) there was considerable overlapping between values obtained in this study and reference values for other horses. Furthermore, substantial resemblance is evident with parameters reported for Pakistani coldblood horses [23]; namely seven (77.8\%) of a total of nine hematological and $6(50 \%)$ of a total of 12 biochemical parameters. This substantial overlapping is not surprising since the compared breeds are coldblood, working horse breeds. However, the lower levels of overlapping between Posavina/Croatian Coldblood and Murinsulaner horse breed [22] were unexpected due to small genetic differentiation among Croatian horse breeds (Posavina, Croatian Coldblood and Murinsulaner) [6]. This might be explained by a bias in obtained Murinsulaner horse values due to a low number of samples (only 33 individuals). There was substantial overlapping for hematological parameters with general values for coldblood horses [21]. However, reference values for both eosinophils $\%$ and count were higher than in other studied horses, due to significantly higher values in mares. This can be explained by the way the animals from our study are kept - mares in an open system biocenosis of woods and marshy meadows, continuously exposed to various parasite infestations, while the stallions are housed in stalls, with much less exposure to external influences factors such as parasites.

Statistically higher values of $\mathrm{Hb}$ and PCV are common in stallions [23]. Baseline hematological values were higher in stallions than in mares and geldings, probably because of the effect of androgens on erythropoiesis [26]. Androgens' effect could be the cause for significantly higher $\mathrm{Hb}$ concentration found in stallions in this study as well. However, although Pritchard et al. [23] found an increase of $\mathrm{Hb}$ and PCV values with age in both stallions and mares in Lahora working horses, we did not find any age associated differences.

Like Gupta et al. [27] we also found higher bilirubin concentrations in stallions than in mares (Table 2), which is probably related to higher RBC count. However, both RBC count and bilirubin values were within the reference range for coldblood horses. The healthy horse has a much higher total serum bilirubin than any of the other domestic species and values as high as $68.4 \mu \mathrm{mol} / \mathrm{L}$ or higher have been observed in otherwise healthy individual [24].

Whereas the majority of biochemical reference values was similar to some other horse breeds, reference values for GGT, CK, ALP, LDH and TP were higher than those found in any other investigation. As reason for this difference, adaptation of Posavina 
and Croatian Coldblood horses to the environment and to the way of breeding reflected in higher values of the mentioned parameters may be proposed.

In this study, a significantly higher $\mathrm{CK}$ activity found in mares as compared to stallions caused a considerably higher reference interval (Table 2) than that in Pakistan working horses [23] and Thoroughbred horses [25]. Serum CK activity is such a sensitive indicator of muscle damage that its large increase in the serum is of clinical significance [28]. The outdoor living conditions of Posavina and Croatian Coldblood mares which are accompanied with more intensive muscle activity and potential muscle damage explains higher levels of CK in mares. In clinically healthy Chilean draught horses elevated muscle enzyme values were observed by Tadich et al. [29]. The effect of exercise type on CK, AST and LDH values has been reported in horses, indicating that higher intensity exercise is related to higher enzyme serum levels [25]. We did not find a significant difference in $\mathrm{LDH}$ mean values between stallions and mares, but the combined LDH reference value was higher than the LDH reference value for coldblood horses and Thoroughbreds. Due to the wide distribution of the enzyme in different tissues (skeletal and cardiac muscle, kidney, liver), increased activity may occur in myocardial infarction, hemolysis, diseases of liver, kidney, lung, skeletal muscle [30]. Since all studied animals were clinically healthy, we propose that the high $\mathrm{LDH}$ values are breed characteristics. A reduction in LDH activity was determined with age [31], unlike Gupta et al. [27] who determined higher activities of LDH in older animals of both sexes. Contrary to that, we did not find an influence of age for any of the parameters.

In this study a statistically higher ALP activity was determined in mares (Table 2). The increased activity of intestinal ALP in horses is associated with parasitic damage of epithelial cells [32]. Increased eosinophil count accompanied with elevated ALP activity in mares found in this study may be associated with parasitic damage of epithelial cells. While Poracova et al. [31] determined the decrease in ALP activity with age, the influence of age was not recorded in this study. The entire reference interval for ALP in studied horses was considerably higher than the maximum in Pakistan working horses.

The significantly higher albumin concentration found in stallions as compared to mares in this study is in accordance with the finding of Gupta et al. [27].

Contrary to Aoki and Ishii [33] who did not find any significant changes in serum calcium concentration between sexes, we found significantly lower values of the total $\mathrm{Ca}$ in mares. Lower $\mathrm{Ca}$ concentrations can occur in herbivores, which consume large amounts of plant species that contain a lot of potassium oxalate [32].

The concentration of magnesium in the blood is associated with nutrition, physical activity and environmental conditions [34]. We found significantly higher values of $\mathrm{Mg}$ concentration in mares (Table 2). The same was found in the Kathiawari horse [27], while Aoki and Ishii [33] did not find significant differences in serum $\mathrm{Mg}$ concentrations between sexes of heavy draft horses. 
Contrary to our finding of elevated urea concentration in mares (Table 2), Pritchard et al. [23] found elevated levels of urea in stallions. Urea concentration in plasma can be increased due to diet with high protein and due to increased protein catabolism [35]. Here again, distinct breeding conditions might contribute to differences in biochemical status of investigated animals. This study further showed significantly higher values of creatinine in mares (Table 2), however no age-related difference was found. Contrary to that, Gupta et al. [27] and Pritchard et al. [23] found that ageing brings an increase in serum creatinine values.

The obtained results enabled the establishment of hematological and biochemical reference values in the blood of Posavina and Croatian Coldblood horses that will in turn support clinical diagnosis and further research into horse physiology.

\section{REFERENCES}

1. Croatian Livestock Center, Central Federation of Horse Breeders of Croatian Posavina horse breed-SSHP: The breeding program of the Croatian Posavina horse breed. Zagreb. 2004, 4.

2. Ljubesic J, Seles J, Sukalic M: The present population of Cold-blood horses in the northwest region of Croatia. Veterinarski Glasnik 1982, 36: 969-977.

3. Mason IL: A World Dictionary of Livestock Breeds, Types and Varieties, $4^{\text {th }}$ Ed, CAB International, 1996, 140.

4. Cacic M, Kolaric S, Mladjenovic M, Tadić D, Korabi N: Geneaology line of Croatian autochthonous horse breed Croatian Posavac. 2004, 1 (in Croatian). Hrvatski stocarski centar.

5. Cacic M, Kolaric S, Kolaric M: Geneaology of dam line of Croatian autochthonous horse breed Croatian Coldblood. 2008, 1 (in Croatian). Hrvatski stocarski centar.

6. Ivankovic A, Ramljak J, Dovc P, Kelava N, Konjacic M: Genetic structure of three Croatian horse breeds: implications for their conservation strategy. Ital J Anim Sci, 2009, 8: 677-689.

7. Galov A, Byrne K, Gomercic T, Duras M, Arbanasic H, Sindicic M, Mihelic D, Kovacic A, Funk SM: Genetic structure and admixture between the Posavina and Croatian Coldblood in contrast to Lipizzan horse from Croatia. Czech J Anim Sci 2013, 58: 71-78

8. Anonymous: Annual report for horse breeding in Republic of Croatia in 2010, with the register of foals. Croatian Centre for horse breeding. State horse farms Đakovo and Lipik. 2011, 43-47.

9. Kovac M: Hrvatski posavac, autochthonous horse of Croatia (in Croatian). Agricultural Centre of Croatia. Livestock Selection Center, Zagreb, 1994, 101-145.

10. Lassen ED, Swardson CJ: Hematology and hemostasis in the horse: normal functions and common abnormalities. Vet Clin N Am-Equine 1995, 11: 351-389.

11. Kedzierski W, Bergero D, Assenza A :Trends of hematological and biochemical values in the blood of young race horses during standardized field exercise tests, Acta Vet-Beograd, 2009, 59: 457-466.

12. Piccione G, Casella S, Monteverde V, Giannetto C, Caola G: Hematological modifications during official 1600 and 2000 meters trot races in standardbred horses, Acta Vet-Beograd, 2008, 58: 325-332. 
13. Jagrič MS, Nemec SA, Zrimšek P, Kramarič P, Kos Kadunc V, Vovk T, Kobal S: Plasma malondialdehyde, biochemical and haematological parameters in standardbred horses during a selected field exercise test, Acta Vet-Beograd, 2012, 62: 53-65.

14. Harvey RB, Hambright MB, Rowe LD: Clinical, biochemical and hematologic values of the American miniature horse: reference values. Am J Vet Res 1984, 45: 97-101.

15. Riber C, Rubio MD, Marquez F, Pinedo M, Munoz A, Castejon F: Haematological changes observed in Andalusian horses with laminitis. J Vet Med Sci 1995, 57: 981-984.

16. Rubio MD, Mundoz A, Santisteban R, Tovar P, Castejon FM: Comparative haematological study of two breeds of foals (Andalusian and Arab) subjected to exercise of progressive intensity. J Vet Med Sci 1995, 57: 311-315.

17. Gonzalez O, Gonzalez E, Sanchez C, Pinto J, Gonzalez I, Enriquez O, Martinez R, Filgueira $G$, White A: Effects of exercise on erythrocyte beta adrenergic receptors and plasma concentrations of catecholamines and thyroid hormones in Thoroughbred horses. Equine Vet J 1998, 30: 72-78.

18. Cebulj-Kadunc N, Bozic M, Kosec M, Cestnik V: The influence of age and gender on haematological parameter in Lippizan horses. J Vet Med A 2002, 49: 217-221.

19. Kastner SBR, Feige K, Weishaupt MA, Auer JA: Heart rate and hematological responses of Quarter horses to a reining competition. J Equine Vet Sci 1999, 19: 127-131.

20. Lauš S, Trailović R, Đoković S, Lazarević M, Trailović D: Comparative analysis of some serum proteins and immunoglobulin $G$ concentration in the blood of Yugoslav Trotter mares and newborn foals, Acta Vet-Beograd, 2012, 62:569-578.

21. Weiss DJ, Wardrop KJ (eds) (2010): Shalm's Veterinary Hematology. $6^{\mathrm{TH}}$ edition, Ed. WileyBlackwell. Ames. Iowa. USA. 1206.

22. Prvanovic N, Kostelic T, Novak B, Cergolj M, Grizelj J, Samardzija M, Filipovic N, Lipar M, Dobranic T: The influence of age and gender on haematological parameters in protected and endangered Murinsulaner horses. In: Proceedings of the XVIth SIVE International Congress / Piccione, Ellena (ed). Bologna $:$ SIVE $=$ Societa Italiana Veterinari per equini. 2010, 30-31.

23. Pritchard JC, Burn CC, Barr ARS, Whay HR: Haematological and serum biochemical reference values for apparently healthy working horses in Pakistan. Res Vet Sci 2009, 87: 389-395.

24. Kaneko J J, Harvey JW, Bruss ML (eds.): Clinical biochemistry of domestic animals, $6^{\mathrm{TH}}$ ed. Academic Press, San Diego. California. USA. 2008, 904.

25. Lacerda L, Campos R, Sperb M, Soares E, Barbosa P, Godinho E, Ferreira R, Santos V, Gonzalez FD: Hematologic and biochemical parameters in three high performance horse breeds from Southern Brazil (in Spanish). Arch Vet Sci 2006, 11: 40-44.

26. Satue K, Hernandez A, Munoz A: Physiological factors in the interpretation of equine hematologic profile in Hematology - Science and Practice. Lawrie, CH (ed). In'Tech. 2012, 577.

27. Gupta AK, Kumar S, Pal Y: Biochemical, haematological and thyroid hormone profile in healthy Indian Kathiawari horses. Asian Austral J Anim 2002, 15: 1215-1221.

28. Lewis HB, Rhodes, DC: Effects of I.M. injections on serum creatine phosphokinase (CPK) values in dogs. Vet Clin Path 1978, 7: 11-3.

29. Tadich N, Mendez G, Wittwer F, Meyer K: Blood biochemical values of load cart draught horses in the city of Valdivia (Chile). Arch Med Vet 1997, 29: 45-53. 
30. Huijgen H J, Sanders GT, Koster RW, Vreeken J, Bussuyt PM: The clinical value of lactate dehydrogenase in serum: a quantitative review. Eur J Clin Chem Clin 1997, 35: 569-575

31. Poracova J, Fazekasova D, Chovancova B: The activity of some enzymes in the blood serum of warm-blooded and cold-blooded horses according to age (in Czech). Czech J Anim Sci 1998, 43: 221-225.

32. Kerr MG: Veterinary laboratory medicine, clinical biochemistry and hematology. $2^{\mathrm{ND}}$ ed. Blackwell Science Ltd. London. 2002, 368.

33. Aoki T, Ishii M: Hematological and biochemical profiles in peripartum mares and neonatal foals (heavy draft horse). J Equine Vet Sci 2011, 32: 170-176.

34. Weiss D, Burger D, Weishaupt MA, Fakler A, Spichiger UE, Giese L, Liesegang A, Wanner M, Riond JL: Effects of a $61.7 \mathrm{~km}$ ride on magnesium and calcium hemostasis in well trained endurance horses. J Equine Vet Sci 2002, 22: 77-83.

35. Burtis CA, Ashwood ER, Bruns DE (eds.): Tietz Textbook of Clinical Chemistry and Molecular Diagnostics. $4^{\mathrm{TH}}$ ed. Elsevier Sounders. St. Louis, Missouri. 2006, 2412.

36. Aiello SE, Moses MA (eds.): The Merck Veterinary Manual Online Merck Sharp \& Dohme Corp. New York, USA. 2012.

\title{
REFERENTNE HEMATOLOŠKE I BIOHEMIJSKE VREDNOSTI SERUMA KOD POSAVSKOG I HRVATSKOG HLADNOKRVNOG KONJA
}

\author{
PAĐEN Lana, GOMERČIĆ Tomislav, ĐURAS Martina, ARBANASIĆ Haidi, \\ GALOV Ana
}

U studiji je obavljeno ispitivanje hematoloških i biohemijskih parametara krvi kod radnih hrvatskih autohtonih rasa konja. Posavski i hrvatski hladnokrvnjak su dve rase konja koje su adaptirane na oštre uslove spoljašnje sredine pa se pretpostavlja da njihovi parametri krvi mogu da budu različiti u poređenju sa drugim rasama. Ispitivanje je obavljeno na 100 kobila i 12 pastuva starosti od 2 do 19 godina. Obavljena je analiza u odnosu na pedeset hematoloških i 19 biohemijskih parametara. Vrednosti koje su dobijene u odnosu na 22 parametra pokazale su značajna preklapanja u poređenju sa drugim rasama konja, pri čemu je ustanovljena značajna podudarnost sa vrednostima koje su karakteristične za pakistanskog radnog konja. Nekoliko referentnih vrednosti je pokazalo statistički značajnan utacaj pola (Hb, ALB, CREA, TBIL i Ca vrednosti su bile značajno veće kod pastuva; EOS, CK, ALP, UREA i Mg vrednosti su bile značajno veće kod kobila). Nijedan parametar koji je ispitivan nije pokazao bilo kakvu varijaciju u odnosu na starost životinja. Prilagođenost posavskog i hrvatskog hladnokrvnog konja na oštre i teške uslove spoljašnje sredine koji podrazumevaju ispašu na poplavljenim pašnjacima, kao i način uzgoja, može da ima posledice na specifične referentne vrednosti ispitivanih parametara. Dobijeni podaci omogućavaju definisanje hematoloških i biohemijskih referentnih vrednosti krvi posavske i hrvatske rase hladnokrvnih konja, a te vrednosti bi omogućavale kliničku dijagnostiku i buduća ispitivanja fiziologije konja. 